\title{
В.Е. Петров
}

Инструментальная философия и ее необходимость в качестве философского проекта

Современная состояние философской профессии не может вызывать должного удовлетворения ее возможностями и результатами, как со стороны общества, так и, прежде всего, со стороны самих профессионаловфилософов. Невостребованность и второстепенность философских идей для политики, науки, культуры и искусства, повседневного уровня жизни людей практически очевидна, и это связывается как с кризисными процессами в непосредственных сферах общественной жизни, так и с кризисом, «смертью» самой философии. Но если наметившийся практический, праксеологический и прикладной поворот в философии в качестве догоняющего «уходящий поезд» жизни пытается нивелировать и преодолеть данный спектр общественных тенденций, то беспомощность и нерезультативность возможностей непосредственно философов как акторов и творцов философского и социокультурного знания сводит этот практический поворот философии фактически на нет.

Нам представляется, что в силу различных социальных и внутренних причин философская интеллектуальная традиция на современном этапе утратила реальные действенные рычаги и инструменты для реализации собственных целей и идей, какими бы они ни были. Современные философы действительно выступают только как теоретики в плохом смысле этого слова, или даже просто как наблюдатели, комментаторы, не имея возможности и даже надежды на исполнение выдвинутых философией проектов, целей и ценностей. Поэтому нам видится, что в структуре системы философского знания должен образоваться (или восстановиться!) в качестве нового проекта такой предметный раздел, как инструментальная философия, в форме комплекса специальных теорий и практик философской деятельности и мышления по реализации самих задач философов и философии. И в отличии от социальной философии, практической философии и иных практикоориентированных направлений современного философского знания, эта предметная область должна быть направлена не сколько на общественное служение и привнесение пользы для внешних, социальных субъектов, сколько на внутреннее применение как особого инструментария для профессиональных философов.

В качестве примера или образца частной инструментальной философии можно привести любую религиозную философию, как теорию, имеющую свой собственный инструментарий (не важно, по спасению души, 
достижению нирваны и т.д.), или медицинскую науку, при всей ее фундаментальности невозможную без выхода на лечебно-практический уровень, в том числе - для самого врача; либо такую область, как управление проектами (в современной учебной практике как предмет «основы проектной деятельности»), аналогично имеющих как теорию, так и эффективный универсальный метод реализации задуманного. Ярким примером включенности практического эффективного инструментария в духовную теорию, на наш взгляд, может служить эзотерика, любая распространенная эзотерическая концепция, например «трансерфинга реальности» В. Зеланда [1], в отличии от философии не являющаяся «чистой непорочной теорией», но предлагающая конкретные рациональные средства для самореализации и использования в повседневной жизни.

Необходимость инструментария для философов на наш взгляд проявилась еще в ранней античной и восточной философии в тех или иных исторических формах. В античной и ранней средневековой философии это такая духовная традиция, как теургия, или философская, элитарная магия [2]. Такая магия принципиально противопоставлялась низовой, народной магии и колдовству. Античный философ мог быть не только интеллектуалом и мудрецом, но и исполнителем, магом по осуществлению собственных идей. В дальнейшем, в Средние века и Новое время весьма близкими к философии были такие традиции, как алхимия [3] и наука, поэтому нам представляется, что инструментарий инструментальной философии может быть двояким как научным, так и ненаучным (теургическим, эзотерическим, магическим), как и сама философия. В итоговой синкретичной форме такой инструментарий мог бы быть связан с техникой философского управления миром и обществом, от глобальных методологий деятельности, теорий деятельности и мышления, целеполагания и принятия решений, до частных и конкретных, таких как ресурсное и логистическое обеспечение поставленных целей.

Одна из основных задач будущей инструментальной философии критериальная оценка возможной профессионально-этической применимости уже существующих философских инструментов, а также создание новых инструментов, соответствующих таким критериям. Например, каковы условия и границы профессиональной деятельности философа в политике, на госслужбе, в коммерческой деятельности, в религиозном поле, в культурном пространстве, науке и образовании и т.д. Какие профессиональные ниши имеют допустимый характер для философа, какие - только при определенных условиях, и какие недопустимы однозначно? Как должна быть организована повседневная и социальная жизнь представителей философской профессии, как действовать философам в ситуации кризиса и ненормативности? 
Какими научными и вненаучными техниками познания должен и вправе пользоваться философ? Допустимы ли в философской деятельности религиозные или эзотерические откровения? Может ли философия быть количественной и «цифровой»? Может ли философ пользоваться таким осуждаемым современной эмпирической наукой методом, как «скрытая этнография» [4], предполагающим эмоциональное сближение исследователя и его респондентов, включая и преодоление барьеров, устанавливаемых этическими нормами научного сообщества, для получения от респондента необходимой информации?

Как обеспечить собственный успех, физическое и психическое здоровье, безопасность личной и профессиональной деятельности, баланс (или однозначный выбор) моральной принципиальности или конформизма? Может ли философ пользоваться эпатажными и неоднозначными средствами достижения целей, например, такими как шантаж, саботаж, лоббирование, манипуляции и спекуляции, дезинформация, скандал, бунт? Многие подобные вопросы уже могли быть озвучены этикой [5] и социальной философией, но не получить финальных решений, как и большинство философских проблем, либо вообще не заявляться и не озвучиваться в официальном философском дискурсе, однако быть актуальными и злободневными для реальной философской практики, и потому требующих неких стандартных, универсальных вариантов решения.

Таким образом, представляется, что современный философ должен быть не только заинтересованным наблюдателем-исследователем, но и социальным актором и субъектом, в связи с чем необходима конкретизация и систематизация существующих, доступных и возможных методов и инструментов философской деятельности и ее обеспечения. Поэтому вслед за прикладным, практическим поворотом в современной философии должен произойти и «инструментальный» поворот в ее содержании и структуре, в программах философского образования.

\section{Литература:}

1. Зеланд В. Трансерфинг реальности / Ступени 1 - 2. - СПб. : Весь, 2008. - 429 с.

2. Петров А.В. Феномен теургии: Взаимодействие языческой философии и религиозной практики в эллинистическо-римский период. - СПб.: Издательство РХГИ; Издательский Дом СПбГУ, 2003. — 415 с.

3. Рабинович В.Л. Алхимия как феномен средневековой культуры. - М.: Наука, 1979.- 427 с. 
4. BLACKMAN S.J. «Hidden ethnography»: Crossing emotional borders in qualitative accounts of young people's lives // Sociology. - L., 2006. -Vol. 41, N 4. - P. 699-716.

5. Сенека Л.А. Нравственные письма к Луцилию; [пер. с латин., авт. послесл., авт. примеч. С. Ошеров]. - Кемерово : Книжное изд-во, 1986. 464 c. 